DOI: $10.30525 / 978-9934-588-61-7-31$

Garasyim Petro

Dr.hab., prof.,

Uniwersytet Jana Kochanowskiego w Kielcach

Zamojski Jerzy

Doktor

Uniwersytet Jana Kochanowskiego w Kielcach

Klym Nadiia

Doctor

Narodowy Uniwersytet Leśnictwa Ukrainy

\title{
HARMONIZOWANIE PODATKÓW POŚREDNICH W KRAJACH NALEŻĄCYCH DO UNII EUROPEJSKIEJ
}

Artykut prezentuje zjawisko harmonizacji podatków pośrednich w krajach należacych do Unii Europejskiej. Praca ta za pomoca dwóch podatków, czyli akcyzy oraz podatku od towarów $i$ ustug przedstawia działania odpowiednich instytucji, głównie Komisji Europejskiej oraz skutki omawianego procesu. Działania te to głównie koordynowanie przestrzegania zasad sprawiedliwej konkurencji przy wymianie towarów $i$ ustug oraz zapewnianie podobnych warunków działalności gospodarczej na terenie Unii. Działania harmonizacji zalicza się do pozytywnych, ale trzeba też pamiętać, że nie wszystkie kraje chętnie chca zmieniać swoje przepisy. Artykut pozwoli wgtębić się $w$ ten temat $i$ odpowie na pytanie czy dotychczasowe działania harmonizacyjne wywołaty zamierzone rezultaty dla ujednolicenia zasad $w$ stosowaniu podatków pośrednich $w$ krajach Unii Europejskiej.

\section{Wprowadzenie}

\subsection{Podatki w gospodarce - znaczenie}

Podatki odgrywają zasadniczą rolę w każdym państwie. Podatek według definicji to przymusowe, bezzwrotne, nieodpłatne oraz publicznoprawne świadczenie pieniężne na rzecz państwa, województwa, powiatu, albo gminy [14]. 
Główną funkcją podatków jest funkcja fiskalna, czyli mają one za zadanie dostarczanie dochodów do budżetów centralnych i lokalnych. Następnie państwo z tych pozyskanych środków realizuje różnego typu zadania, dla przykładu bez podatków nie funkcjonowałoby państwowe szkolnictwo, wymiar sprawiedliwości, czy też państwowa służba zdrowia. To właśnie z podatków mieszkańców i przedsiębiorstw działających na terenie danego kraju utrzymywane są instytucje publiczne, drogi, orliki itp.

Podatki mają też inne funkcje. Funkcja redystrybucyjna polega na tym, że podatnicy oddają część swoich dochodów państwu, a państwo z kolei może finansować swoje wydatki. Trzeba zwrócić uwagę na to, że czasem państwo dokonuje niewłaściwych inwestycji, np. ostatnio rząd zdecydował o przekazaniu 2 mld zł na rozwój mediów społecznych. Według części społeczeństwa te pieniądze powinny być skierowane na opieke zdrowotną obywateli. Państwo powinno dbać o rynek pracy, przyszłość młodych ludzi, a czasem finansuje «kontrowersyjne» rzeczy, często (choć nie zawsze) dla doraźnego zysku politycznego.

Do funkcji redystrybucyjnej podobna jest, pod względem treści ekonomicznej funkcja alokacyjna, która opiera się na przekazywaniu dóbr i zasobów jednych podmiotów do drugich. Ta funkcja głównie ma za zadanie wpierać produkcje i kształtować odpowiednio zasady przekazywania majątku oraz dóbr i zasobów pomiędzy tymi podmiotami.

Podatek cechuje również funkcja stymulująca, która polega na wpływaniu na warunki, tempo i rozwój jednostek. Podatek tutaj stanowi główną informacje na temat decyzji $\mathrm{w}$ przedsiębiorstwie, np. zatrudnienie pracowników, likwidacja działalności, czy też zakup dóbr. W praktyce ta funkcja prezentuje się $\mathrm{w}$ ulgach i zwolnieniach podatkowych, ale również trzeba zwrócić uwagę na negatywną sferę, która przejawia się $\mathrm{w}$ dławieniu konkurencji oraz sterowaniu gospodarką przez urzędników.

System podatkowy również ma za zadanie zmniejszyć różnice majątkowe $\mathrm{w}$ społeczeństwie. Co przejawia się $\mathrm{w}$ wyborze opodatkowania progresywnego i degresywnego. Państwo może też nakładać większe podatki na dobra luksusowe, a dobra pierwszej potrzeby opodatkowuje za pomocą mniejszych stóp podatkowych.

Często da się zauważyć niechęć społeczeństwa do tych obowiązkowych świadczeń, obywatele niekiedy unikają lub uchylają się od płacenia nich. Ekonomiczną przyczyną tego zjawiska jest efekt Laffera. Opiera się on na zasadzie, że wpływy podatkowe do budżetu stopniowo się zmniejszają, po osiągnięciu pewnego punktu. Gdy w państwie są stosowanie wysokie stopy podatkowe, to ludność unika płacenia podatków, zaś niskie stopy podatkowe powodują wyższą skłonność do podjęcia inwestycji i wzrost produkcji. W takiej sytuacji przedsiębiorcy prowadzą działalność zgodną z prawem oraz przestają unikać płacenia podatków. Dlatego ważne jest dla państwa dobranie takiej polityki fiskalnej, aby podatnicy prowadzili legalną działalność gospodarczą i legalnie zatrudniali pracowników. 


\subsection{Podatki w gospodarce - podzial}

Podatki są klasyfikowane w różny sposób. Najczęściej można je podzielić biorąc pod uwagę podmiot opodatkowania. Wyróżnia się tutaj 3 typy podatków:

- podatek dochodowy - pobierany od dochodów osób fizycznych i prawych;

- podatek konsumpcyjny - pobierany od dóbr i usług, które są przedmiotem obrotu;

- podatek majątkowy - nakładany na posiadany majątek.

Drugi podział pokazuje inną klasyfikacje podatków, ze względu na przerzucalność podatkową:

- podatki bezpośrednie - podatek nałożony na majątek oraz dochód, np. podatek gruntowy;

- podatki pośrednie - podatek nałożony na wydatki, zalicza się tutaj głównie VAT i akcyze.

Jest to jeden $\mathrm{z}$ najstarszych podziałów. Podatki bezpośrednie są bezpośrednio odprowadzane do Urzędu Skarbowego, zaś pośrednie polegają na tym, że konsument płaci te przymusowe świadczenie przy zakupie jakiegokolwiek dobra lub usługi.

\subsection{Harmonizacja podatkowa - istota zjawiska}

$\mathrm{Z}$ podatkami związana jest $\mathrm{w}$ dużym stopniu ich harmonizacja, stosowana głównie w celu integracji gospodarczej państw członkowskich UE. Harmonizacja podatków jest procesem, w rezultacie którego systemy podatkowe różnych państw stają się podobne. Harmonizacja oznacza ujednolicenie systemów podatkowych państw. Stosowana jest w celu wyeliminowania problemów związanych z przepływem towarów, kapitału oraz usług pomiędzy krajami, czyli ma na celu zapewnienie prawidłowego funkcjonowania jednolitego rynku. Przyjęcie przepisów harmonizacyjnych pomogło $\mathrm{w}$ zniesieniu przeszkód przy przepływnie towarów, np. zniesienie ceł $\mathrm{i}$ ograniczeń ilościowych $\mathrm{w}$ handlu. Harmonizacja podatkowa także umożliwiła poszanowanie właściwej konkurencji, praw konsumenta oraz ochronę środowiska [1;9].

Zjawisko harmonizacji podatków jest skutkiem działań Komisji Europejskiej oraz działań i procesów kształtowanych na rynku. Harmonizacja podatkowa odnosi się zarówno do podatków pośrednich oraz bezpośrednich. Ten artykuł poświęcony jest podatkom pośrednim, gdyż to one mają większe znaczenie dla harmonizacji podatkowej. Głównie dlatego, że dobra i usługi często są sprzedawane (eksport) lub kupowane (import) do krajów zagranicznych. Harmonizacja podatków pośrednich ma pomóc w przekazywaniu tych dóbr i usług, poprzez zniesienie ceł i ograniczeń ilościowych $\mathrm{w}$ handlu, ale także ma określać odpowiednie przepisy prawne dla krajów członkowskich, takie jak: wysokość stawek podatkowych, przedmiot czy podmiot opodatkowania. 
Celem tej pracy jest ukazanie istoty tego zjawiska na przykładzie wybranych podatków pośrednich, celem jest również zaprezentowanie skutków jakie powoduje harmonizacja w krajach UE. Artykuł odpowie na pytanie czy dotychczasowe działania harmonizacyjne wywołały zamierzone skutki dla ujednolicenia zasad w stosowaniu podatków pośrednich.

\section{Rozwinięcie}

\subsection{Istota harmonizacji podatków pośrednich}

Podatki pośrednie, czyli te świadczenia pieniężne, które są płacone przy kupowaniu danego dobra lub usługi. Największe znaczenie ma tutaj podatek VAT oraz akcyza. Harmonizacja ma głównie obrany cel, aby wysokości stawek podatków w różnych państwach członkowskich Unii Europejskiej były podobne. Po to aby uniknąć dużych różnic w cenach tych samych lub podobnych produktów. Harmonizacja tych podatków wiąże się $\mathrm{z}$ ideą wspólnego rynku państw członkowskich, która zakłada przede wszystkim stosowanie jednolitych ceł $i$ innych opłat pieniężnych przez kraje członkowskie; ta koncepcja polega też na swobodzie działalności gospodarczej państw członkowskich i stworzeniu na wolnym rynku neutralnych warunków konkurencji. Różne stawki podatków mają duży wpływ na wybór dóbr i usług przez konsumentów.

Harmonizacja strzeże właściwej konkurencji na rynku. W Traktacie o Funkcjonowaniu Unii Europejskiej (TFUE art. 101-109) [13] są wskazane reguły konkurencji na rynku wewnętrznym. Do tych zasad należą przede wszystkim: zakaz porozumień ograniczających konkurencję, zakaz nadużywania pozycji dominującej przez przedsiębiorstwa oraz w niektórych przypadkach zakaz koncentracji i przejęć o wymiarze wspólnotowym.

Należy zaznaczyć, że harmonizacja to proces bardzo długi i żmudny, wynika to z faktu, że kraje członkowskie niechętnie chcą zmieniać swoje prawa podatkowe, aby dostosować się do wytycznych UE. Harmonizacja podatkowa w przyszłości ma za cel wykreować jednolity system podatkowy, stworzony z połączenia wszystkich rynków krajów członkowskich UE. Musi on być przychylny wszystkim państwom UE, aby przekazywanie dóbr i usług pomiędzy krajami było płynne i obyło się bez zbędnych problemów, aby w przyszłości zjednoczyć Europę do jednego superpaństwa - Stany Zjednoczone Europy.

Decyzje odnośnie owej harmonizacji podejmowane są na szczeblu UE, wtedy kiedy odnoszą się do jednolitego rynku wewnętrznego. Dalsze decyzje mogą być podejmowane przez kraje członkowskie oraz samoistnie poprzez działanie rynku [9].

\subsection{Podatek od towarów i usług - VAT}

\subsubsection{Ogólne informacje o podatku VAT}

Historia podatku VAT sięga roku 1920. Generalnie za twórcę tego podatku uważa się Francuza Maurice Lauré, choć jako pierwszy w swoich pracach przedstawił zarys tego podatku przedsiębiorca niemiecki Carl Friedrich von Siemens [7]. 
Podatek VAT nosi nazwę podatku od wartości dodanej, choć w Polsce znany jest pod nazwą podatku od towarów i usług, co oddaje jego istotę. Chodzi o to, że jest on nakładany na towary i usługi. Podatek od towarów i usług zaliczany jest do podatków pośrednich, jest doliczony do ceny towaru lub usługi. Podatek VAT finalnie obciąża rachunek konsumenta. A prawo odprowadzania różnicy między podatkiem należnym a naliczonym do Urzędu Skarbowego spoczywa na sprzedawcy.

W Polsce ten podatek został wprowadzony w dniu 8 stycznia $1993 \mathrm{r}$. eliminując obowiązujący $\mathrm{w}$ tym czasie podatek obrotowy. Wraz $\mathrm{z}$ przystąpieniem Polski do Unii Europejskiej nastąpiła aktualizacja tego podatku w 2004 r. co reguluje Ustawa o podatku od towarów i usług z dnia 11 marca $2004 \mathrm{r}$.

Stawką podstawową w Polsce tego podatku jest 23 procent, ale $\mathrm{W}$ niektórych przypadkach może być niższa i wynosić $8,7,5$ lub nawet $0 \%$.

\subsubsection{Harmonizacja podatku VAT}

Kluczowe lata dla wprowadzenia jednolitego systemu opodatkowania VAT to przedział od 1967 do 1977. W tych latach zostało ogłoszone sześć dyrektyw, które miały za zadanie ukształtować wspólny system VAT w krajach Unii Europejskiej. Kluczowe wpływy miały trzy spośród sześciu dyrektyw:

Tzw. «Pierwsza Dyrektywa» przyjęta dnia 11 kwietnia 1967 r. w sprawie harmonizacji ustawodawstw Państw Członkowskich odnoszących się do podatków obrotowych.

Tzw. «Druga Dyrektywa» z 11 kwietnia 1967 r. w sprawie harmonizacji ustawodawstw Państw Członkowskich dotyczących podatków obrotowych struktura i zasady stosowania wspólnego systemu podatku od wartości dodanej.

Najważniejsza tzw. «Szósta Dyrektywa» z dnia 17 maja 1977 r. w sprawie harmonizacji przepisów państw członkowskich odnoszących się do podatków obrotowych - wspólny system podatku od wartości dodanej [3].

Pierwsza Dyrektywa miała na celu zobligować kraje UE do wprowadzenia podatku od wartości dodanej i tym samym wykluczyć obowiązujący podatek obrotowy. [9] Dyrektywa ta jednocześnie formuluje takie cechy podatku VAT jak: powszechność, stosowanie podatku w każdym etapie obrotu gospodarczego oraz faktyczność opodatkowania konsumpcji.

Druga Dyrektywa wyznaczyła strukturę i zastosowanie wspólnego systemu opodatkowania podatkiem VAT. Za pomoca tej dyrektywy ukazano, że dostawa towarów lub materiałów oraz świadczenie usług podlegają opodatkowaniu tym podatkiem.

Te dwie dyrektywy określały tylko ogólne zasady opodatkowania towarów i usług. W tym czasie były widoczne nierówności w różnych krajach UE pod względem opodatkowania podatkiem VAT. Dlatego wydano Szóstą Dyrektywę. Stała się ona kluczowa dla doprecyzowania ogólnych zasad dotyczących omawianego podatku. Określała przedmiot oraz podstawę 
opodatkowania, zasady odliczania podatku małych przedsiębiorstw, rolnictwa, i także inne istotne kwestie dla owego podatku.

Przez kolejne lata pojawiały się aktualizacje Szóstej Dyrektywy, przez co zmieniły się jej pierwotne postanowienia. Dla przejrzystości wprowadzono Dyrektywę z dnia 28 listopada 2006 r. która obowiązuje do dzisiaj, odwołując tym samym Pierwszą i Szóstą Dyrektywę. Skoncentrowała ona nowe zasady dotyczące podatku od towarów i usług [5]. No i nie wyszło do dziś dnia.

\subsubsection{Stawki podatku VAT przy harmonizacji podatkowej}

Od grudnia 2005 r. najniższa obowiązujacca stawka podstawową podatku VAT w Unii Europejskiej jest 15\%. Mogą występować też stawki obniżone oraz specjalne. Obniżone stawki obowiązują wtedy, gdy występuje ograniczona liczba towarów bądź usług. Zaś stawki specjalne stosuje się dla niektórych towarów i usług, np. w Polsce obowiązuje stawka ośmioprocentowa na dostawy azotanu wapnia i azotanu magnezu. [12]

Państwa członkowskie mogą same ustalać stawki podstawowe powyżej $15 \%$. Jeżeli chodzi o stawki obniżone to są one wprowadzane w danym kraju za zgodą innych krajów należących do UE. Komisja Europejska ma za zadanie regulować raporty dotyczące stosowania stawek obniżonych podatku VAT przez kraje członkowskie UE [9]. Celem Dyrektywy Rady UE 2006/112/WE z dnia 28 listopada 2006 r. była harmonizacja podatku VAT w krajach należących do UE, ale nie zostało to zrealizowane w stu procentach. Można zauważyć duże rozbieżności w wysokości tego podatku, co pokazuje tabela 1.

Tabela 1. Żródło: https://europa.eu/youreurope/business/taxation/vat/vatrules-rates/index_pl.htm\#shortcut-8 [8].

Analizując tę tabelę, widać, że amplituda stawek podstawowych jest dość duża, ale nie przekracza 10 punktów procentowych. Najniższa standardowa stawka podatku VAT wynosi $17 \%$, obowiązuje ona w Luksemburgu, a najwyższa to $27 \%$ i jest stosowana na Węgrzech. Różnice są też widoczne przy stawkach obniżonych. Minimalna wartość wynosi $4 \%$ zaś maksymalna to $18 \%$. Dania natomiast jest przykładem państwa, w którym nie występują obniżone stawki tego podatku.

Wydaje się, że ujednolicenie zasad przy stosowaniu stawek tego podatku jest niezbędne, gdyż rozbieżności wywołują niekorzystne skutki dla funkcjonowania rynku wewnętrznego, np. dumping podatkowy oraz ograniczenie rozwoju gospodarczego krajów członkowskich. Harmonizacja tego podatku może przyczynić się do niwelowania przenoszenia działalności do państw o lepiej działającym systemie podatkowym. Podobne wysokości stawek na pewno poprawią funkcjonowanie rynku wewnętrznego, np. poprzez łatwiejszy przepływ towarów pomiędzy krajami Wspólnoty. 
Stawki VAT obowiązujące w krajach UE

\begin{tabular}{|l|c|c|}
\hline \multicolumn{1}{|c|}{ Państwo } & Podstawowa stawka VAT & Zredukowane stawki VAT \\
\hline Luksemburg & $17 \%$ & $14 \%, 8 \%, 3 \%$ \\
\hline Malta & $18 \%$ & $5 \%, 7 \%$ \\
\hline Cypr & $19 \%$ & $9 \%, 5 \%$ \\
\hline Niemcy & $19 \%$ & $7 \%$ \\
\hline Rumunia & $19 \%$ & $9 \%, 5 \%$ \\
\hline Austria & $20 \%$ & $13 \%, 10 \%$ \\
\hline Bułgaria & $20 \%$ & $9 \%$ \\
\hline Estonia & $20 \%$ & $9 \%$ \\
\hline Francja & $20 \%$ & $10 \%, 5,5 \% .2,1 \%$ \\
\hline Słowacja & $20 \%$ & $10 \%$ \\
\hline Belgia & $21 \%$ & $12 \%, 6 \%$ \\
\hline Czechy & $21 \%$ & $15 \%, 10 \%$ \\
\hline Hiszpania & $21 \%$ & $10 \%, 4 \%$ \\
\hline Holandia & $21 \%$ & $6 \%$ \\
\hline Litwa & $21 \%$ & $9 \%, 5 \%$ \\
\hline Łotwa & $21 \%$ & $12 \%, 5 \%$ \\
\hline Słowenia & $22 \%$ & $9,5 \%$ \\
\hline Włochy & $22 \%$ & $10 \%, 5 \%, 4 \%$ \\
\hline Irlandia & $23 \%$ & $13,5 \%, 9 \%, 4,8 \%$ \\
\hline Polska & $23 \%$ & $8 \%, 5 \%$ \\
\hline Portugalia & $23 \%$ & $13 \%, 6 \%$ \\
\hline Finlandia & $24 \%$ & $14 \%, 10 \%$ \\
\hline Grecja & $24 \%$ & $13 \%, 6 \%$ \\
\hline Chorwacja & $25 \%$ & $13 \%$ \\
\hline Dania & $25 \%$ & - \\
\hline Szwecja & $25 \%$ & $12 \%, 6 \%$ \\
\hline Węgry & $27 \%$ & $18 \%, 5 \%$ \\
\hline & & \\
\hline & & \\
\hline
\end{tabular}

\subsubsection{Harmonizacja podatku VAT w UE teraz i w przyszłości - krótkie podsumowanie}

Do tej pory można zauważyć konflikty między krajami członkowskimi z powodu dużej rozbieżności w stawkach podatku VAT w różnych krajach Unii Europejskiej. Najczęściej napięcia te widać w krajach tzw. «starej Unii», gdyż często te kraje nie wprowadziły odpowiednich przepisów podatkowych, co skutkuje możliwością konkurencji z innymi państwami UE oraz kraje mogą nie udzielać zgody na zmiany w systemie podatkowym Unii Europejskiej. Można zwrócić uwagę na to, że samo opodatkowanie towarów nie powoduje większych sporów między członkami UE, zaś opodatkowanie usług budzi wiele napięć między państwami członkowskimi. Głównie dlatego że usługi są głównym instrumentem konkurencji podatkowej w UE [9].

Według liberalnego podejścia, harmonizacja stawek VAT-u powinna działać na zasadzie swobody. Chodzi o to, by stawki podatku VAT w krajach 
członkowskich ustalały się bez żadnych wymogów innych krajów. Przeciwnicy tego podejścia obawiają się, że taka swoboda oznaczałaby, że każde państwo stosowałoby najniższe stawki [9].

Harmonizacja podatku VAT jest procesem długim i nie jest zakończona, głównie dlatego że państwa członkowskie niechętnie podchodzą do zmian systemu opodatkowania podatku VAT. Z harmonizacją podatkową wiąże się zjawisko konkurencji podatkowej, która polega na tym że działalność gospodarcza przenoszona jest do państw z lepszym systemem podatkowym. Prawdopodobnie konkurencja podatkowa byłaby mniejsza, gdyby obniżone stawki w krajach członkowskich były zrównoważone. Organy nadrzędne Unii mają świadomość odnośnie niekoniecznie dobrze funkcjonującym systemie podatkowym. Starają się go ulepszać lecz niechęć państw członkowskich bardzo w tym przeszkadza.

\subsection{Podatek akcyzowy}

\subsubsection{Ogólne informacje o akcyzie}

Podatek akcyzowy należy do grupy podatków pośrednich. Jest nakładany na niektóre wyroby, aby zwiększyć dochody do budżetu państwa lub zminimalizować spożycie tych wyrobów. Podatek pobierany jest od energii, paliw oraz używek, zaś obowiązek jego płacenia spoczywa na finalnym konsumencie.

W Polsce podatek akcyzowy funkcjonował od czasów I wojny światowej. W 1948 r. został zastąpiony przez podatek obrotowy. Po około 45 latach został przywrócony i funkcjonuje do dzisiaj. Obecnie w Polsce akcyzę reguluje ustawa $\mathrm{z} 6$ grudnia 2008 r. o podatku akcyzowym oraz rozporządzenia Ministra Finansów zgodne z ustawą.

Stawki akcyzy można ustalić kwotowo lub procentowo. Stawki procentowe ustalone są dla samochodów osobowych i wyrobów tytoniowych. Stawki kwotowe są zastosowane przy sprzedaży paliwa, alkoholu i energii elektrycznej. Często akcyza charakteryzuje się wysoką stawkę, niekiedy stanowi $75 \%$ ceny danego produktu, dlatego ma duży udział w wpływach do budżetu państwa.

\subsubsection{Harmonizacja podatku akcyzowego}

Ujednolicanie akcyzy w krajach Unii Europejskiej jest procesem dość długim i żmudnym, ponieważ występują różnice przy stosowaniu tego podatku w krajach członkowskich oraz podatek ten charakteryzuje się dość specyficznym charakterem, gdyż jest nakładany na niektóre wyroby.

Zasadnicze zasady odnośnie harmonizacji akcyzy zostały zawarte w dyrektywach z 1992 r. Reguły te odnosiły się do obrotu wyrobami podlegającym opodatkowaniu podatkiem akcyzowym oraz do sposobu poboru wyrobów $\mathrm{w}$ krajach należących i nienależących do UE. Ponadto zostały ustalone minimalne stawki tego podatku [9]. W 2008 r. nastąpiła aktualizacja tej dyrektywy i uchyliła ona obowiązującą dotychczas dyrektywę z 1992 r. wprowadzając nowe, ogólne zasady stosowania podatku akcyzowego. 
Aby istniał wspólny system opodatkowania akcyzy w krajach członkowskich bez żadnych przeszkód, potrzebna była harmonizacja zasad przemieszczenia się towarów pomiędzy tymi państwami. Po to, aby istniał handel pomiędzy państwami UE bez kontroli granicznych. Komisja Europejska podejmuje odpowiednie działania, aby poprawić funkcjonowanie wspólnego systemu. Dla przykładu, aby ujednolicić zasady stosowania akcyzy przez kraje Unii Europejskiej, ważną kwestią stało się rozszerzenie systemu opodatkowania akcyzy odnośnie paliw mineralnych. Inne działania dotyczące harmonizacji to, np. usuwanie niedoskonałości w nadzorze nad obiegiem wyrobów akcyzowych w UE, podwyższenie stawek minimalnych, które wywołało niechęć przez niektóre państwa; głównie $\mathrm{z}$ powody zwiększenia kosztów produkcji oraz utrzymania przedsiębiorstw [9].

Obecnie harmonizacja podatku akcyzowego ma za zadanie ujednolicać w krajach członkowskich stawki, podstawę i przedmiot opodatkowania. Aktualnie prawo podatkowe odnośnie akcyzy wskazuje wyroby podlegające temu podatkowi, sposób wyznaczenia podstawy opodatkowania i minimalną stawkę akcyzy dla poszczególnych grup wyrobów. Jednak te działania nie zapewniają jednolitego poziomu stawek owego podatku w krajach UE. Pokazuje to dobrze wysokość obowiązujących stawek na alkohol etylowy:

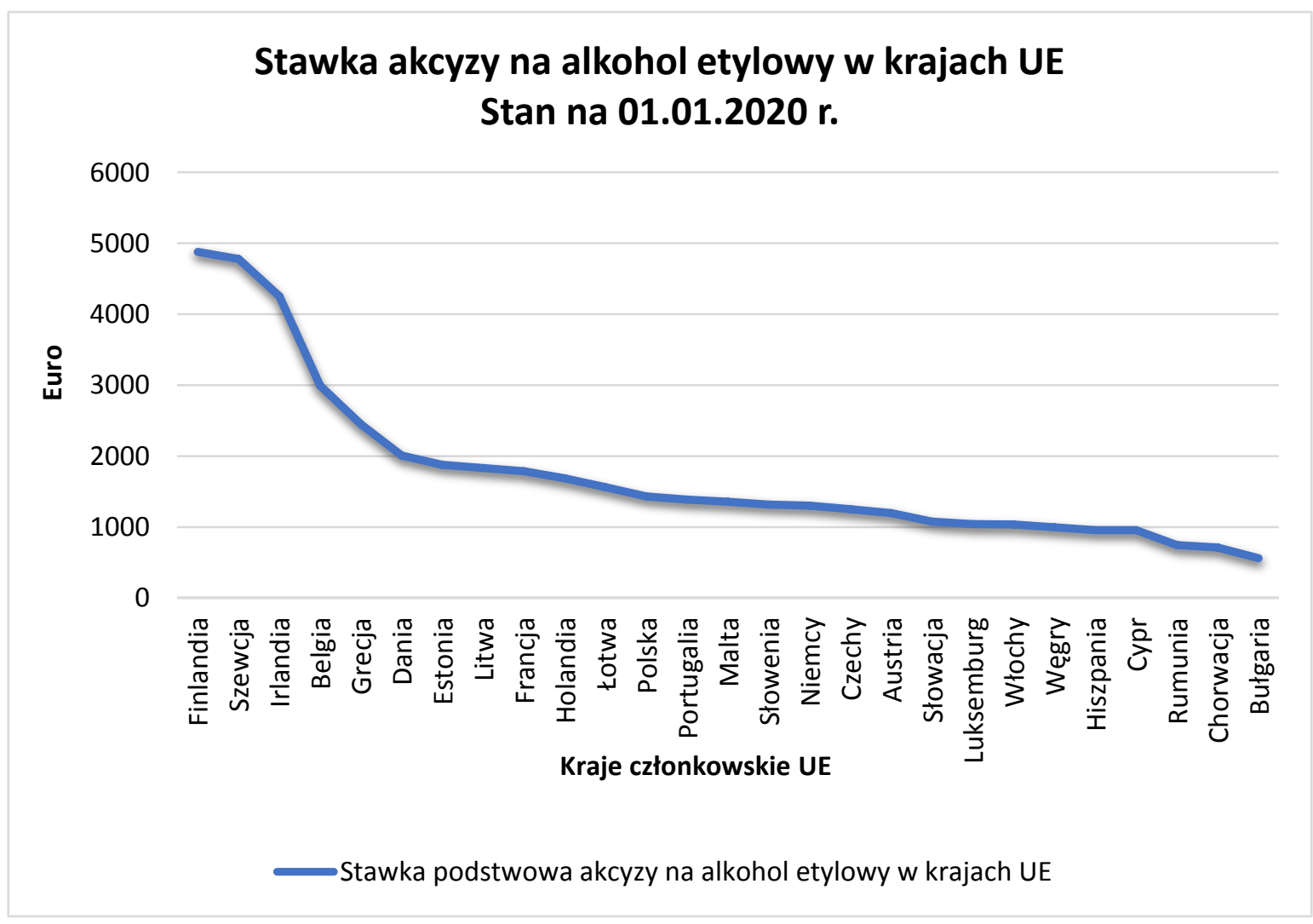

Standardowa stawka akcyzy na alkohol etylowy od 1 hektolitra alkoholu etylowego $100 \%$ VOL. Zawartego w gotowym wyrobie

Źródto: http://ec.europa.eu/taxation_customs/tedb/taxSearch.html [6] 
Wszystkie kraje należące do Unii Europejskiej przestrzegają obowiązku minimalnego progu stawki podatku akcyzowego, który wynosi 550,00 euro za 1 hektolitr alkoholu etylowego. Na podstawie powyższego wykresu można zauważyć dużą rozbieżność pomiędzy najwyższą a najniższą stawką akcyzy na alkohol etylowy. Największa jest w Finlandii i sięga około 5000 euro / 1 hl, Najmniejsza wynosi ok 560 euro za 1 hektolitr alkoholu etylowego i nakładana jest $\mathrm{w}$ Bułgarii. Widać, że brakuje określenia stawki maksymalnej, co ułatwiłoby porozumiewanie się państw odnośnie handlu tymi produktami.

Warto zwrócić uwagę na to, że ta rozbieżność wpływa dość mocno na wybory konsumentów, ze względu na cenę danego produktu, a podatek akcyzowy stanowi jej dużą część. Dlatego ważna jest harmonizacja w tym aspekcie.

Akcyza jest opodatkowana tylko jeden raz i jest nakładana na wyrób wraz z chwilą dopuszczenia do konsumpcji w kraju UE. Dyrektywa jako «instrument» oddziaływania harmonizacji w krajach członkowskich określiła metody i warunki pobierania tego podatku, w aspekcie wyrobów wytworzonych w krajach UE i tych które pochodzą z importu od innych państw, nienależących do Unii Europejskiej. W celu ułatwienia przemieszania się towarów podlegającym akcyzie został wdrożony System Przemieszczania oraz Nadzoru Wyrobów Akcyzowych (EMCS). Dzięki temu zmniejszyły się obciążenia finansowe i administracyjne dla podatników, poprawiło się również bezpieczeństwo fiskalne dotyczące obrotu tymi wyrobami [2].

\subsubsection{Harmonizacja podatku akcyzowego w UE teraz i w przyszlości - krótkie podsumowanie}

Harmonizacja akcyzy nie należy do najprostszych działań, podobnie jak harmonizacja podatku od wartości dodanej. Głównie dlatego, że jest nakładana tylko na niektóre wyroby oraz z tego względu, że trzeba połączyć ze sobą zapewnienie wydajności fiskalnej $\mathrm{z}$ ochroną poziomu życia społeczeństwa [11].

Stosowanie różnych działań harmonizacyjnych dało wiele skutków, nie do końca takich, na które UE liczyła. Do tych negatywnych można zaliczyć ustanowienie stawek minimalnych, które miały za zadanie przybliżyć te wartości do różnego poziomu, jednak tak się nie stało. Do tej pory widoczne są spore różnice w wysokościach tych stawek między krajami członkowskimi. Pozytywnie ocenia się działania harmonizacyjne polegające na określeniu wyrobów objętych tym podatkiem, określnie podstawy opodatkowania i katalog zwolnień przy stosowaniu akcyzy.

\section{Podsumowanie}

$\mathrm{W}$ pracy ukazano, że harmonizacja podatków jest istotnym elementem $\mathrm{w}$ funkcjonowaniu rynku wewnętrznego. Jest niezbędna pod względem ujednolicania systemów podatkowych w krajach Unii Europejskiej [4]. Wyodrębnia ona prawnie przepisy, do których kraje członkowskie muszą się stosować, np. minimalne stawki podatku VAT, czy akcyzy. 
Harmonizacja jak najbardziej zalicza się do pozytywnych działań Unii Europejskiej, ale do tej pory nie przyniosła odpowiednich skutków. Nadal są widoczne rozbieżności w przepisach podatkowych krajów członkowskich.

Celem harmonizacji jest ukształtowanie jednolitego rynku w obrębie Unii Europejskiej, który działałaby bez większych przeszkód. Jest to możliwe, pod warunkiem dostosowania wszystkich systemów państw należących do Unii Europejskiej i połączenia go w jeden, funkcjonujący prawidłowo system podatkowy. Tak się nie stało do dzisiaj, głównie z powodu indywidulanych systemów państw UE, które ciężko jest zmienić. Państwa te nie chcą zmieniać swoich przepisów ze względu na ochronę poziomu życia obywateli. Każda zmiana przepisów niesie obawy, a czasem zamęt w społeczeństwie, dlatego rząd w każdym państwie chce powoli wprowadzać zmiany $\mathrm{w}$ systemie podatkowym.

Przy harmonizacji podatku od wartości dodanej, kluczowym problem staje się brak maksymalnej granicy. Stosuje się tylko minimalną stawkę i wynosi ona $15 \%$. Państwa mają swobodę w stosowaniu stawek VAT. Z tego względu pojawiają się istotne różnice $\mathrm{w}$ wysokościach podatku nakładanego na towary i usługi przez kraje członkowskie. Jeżeli chodzi o stawki zredukowane, tez pojawiają się rozbieżności $\mathrm{w}$ ich wysokościach. Trzeba pamiętać, że są one akceptowane przez inne kraje członkowskie. Dlatego, państwa podejmując swoje indywidualne decyzje odnośnie stawek VAT, muszą mieć na uwadze ich wpływ na inne kraje należące do UE.

Ujednolicenie stawek podatku od wartości dodanej w znacznym stopniu pomoże ułatwić funkcjonowanie wewnętrznego rynku na terenie Unii Europejskie. Komisja Europejska również pracuje nad ograniczeniem stosowania zredukowanych stawek i zwolnień podatkowych oraz rozszerzenie podstaw podatkowych, głównie dlatego, aby zwiększyć tempo wzrostu gospodarczego.

Harmonizacja akcyzy także należy do długiego procesu i dość trudnego, ale odgrywa ważną rolę, gdyż ujednolicanie zasad funkcjonowania systemu podatkowego akcyzy gwarantuje swobodny przepływ produktów objętych akcyzą. Handel tymi produktami należy do jednego $\mathrm{z}$ najtrudniejszych, ponieważ często dochodzi do nadużyć podatkowych. Należy tu wymienić przemyt, nadużywanie obniżek lub zwolnień podatkowych. Dlatego bardzo ważne jest porozumienie krajów członkowskich w tej kwestii.

Podobnie jak przy podatku VAT, da się zauważyć dysproporcje przy stosowaniu stawek podatku akcyzowego przez państwa UE. Brak tutaj górnej granicy. Kraje członkowskie mają swobodę przy stosowaniu stawek, co powoduje liczne problemy przy obrocie tymi wyrobami. Różnice między krajami członkowskimi można też zaobserwować w wysokościach podstaw podatkowych oraz określeniu ilości towarów podlegających akcyzie. Procesy harmonizacji akcyzy pozwolą na lepsze funkcjonowanie rynku wewnętrznego oraz zmniejszą problemy z przepływem towarów i produktów. 


\section{Używana literatura}

1. «Harmonizacja podatkowa w procesie integracji krajów UE - zarys problemu» Suwalski Krzysztof, http://www.bibliotekacyfrowa.pl/Content/27247/Integracja_gospodarcza_ w_rozszerzonej_UE_07.pdf

2. «Harmonizacja podatku akcyzowego jako istotny czynnik integracji gospodarczej» Nierówności Społeczne a Wzrost Gospodarczy, nr 37 (1/2014) ISSN 1898-5084 ISBN 978-83-7996-020-0, Sowa Bożena

3. «Harmonizacja VAT w Unii Europejskiej» Anna Więckowska, https://www.ksb.biz.pl/Content/uploaded/files/stud\%20podypl/mechanizmy\%20Euro\%20$\% 20$ prace\%202016/Wi\%C4\%99ckowska\%20Anna.pdf

4. «Istota harmonizacji podatkowej» Jeleńska Anna, http://www.trp.umk.pl/download/ trp2013/ISTOTA_HARMONIZACJI_PODATKOWEJ.pdf

5. «Mechanizmy Integracji Europejskiej», IV Kongres Kół Naukowych Uniwersytetu im. Adama Mickiewicza w Poznaniu, Poznań 2015, http://kongres.home.amu.edu.pl/wpcontent/uploads/2015/05/mechanizmy.pdf

6. http://ec.europa.eu/taxation_customs/tedb/taxSearch.html

7. https://biznes.interia.pl/gospodarka/news-skad-sie-wzial-vat,nId,3879767

8. https://europa.eu/youreurope/business/taxation/vat/vat-rules-rates/index_pl.htm\#shortcut-8

https://www.ksb.biz.pl/Content/uploaded/files/stud\%20podypl/mechanizmy\%20Euro\% 20-\%20prace\%202016/Wi\%C4\%99ckowska\%20Anna.pdf

9. Oręziak Leokadia «Konkurencja podatkowa i harmonizacja podatków w ramach Unii Europejskiej. Implikacje dla Polski» Wyższa Szkoła Handlu i Prawa, Warszawa 2007

10. Pierwsza dyrektywa Rady z dnia 11 kwietnia 1967 r. w sprawie harmonizacji ustawodawstw Państw Członkowskich dotyczących podatków obrotowych (67/227/EWG) art. 1.

11. Pomorska A., Szołno-Koguc J., Wójtowicz K. «Proces dostosowywania polskich podatków pośrednich do standardów Unii Europejskiej» Wydawnictwo Uniwersytetu Marii Curie-Skłodowskiej, Lublin 2003

12. Rozporządzenie Ministra Finansów z dnia 23 grudnia 2013 r. rozdział 2, paragraf 3.4 punkt 3. http://prawo.sejm.gov.pl/isap.nsf/download.xsp/WDU20130001719/O/ D20131719.pdf

13. Traktat o funkcjonowaniu Unii Europejskiej (TFUE) art. 101-109, https://eurlex.europa.eu/legal-content/PL/TXT/PDF/?uri=CELEX:12012E/TXT\&from=PL

14. Ustawa $\mathrm{z}$ dnia 29 sierpnia 1997 r. Ordynacja podatkowa, art. 6. http://prawo.sejm.gov.pl/isap.nsf/download.xsp/WDU19971370926/U/D19970926Lj.pdf 